\title{
Using Problem-Based Learning Models to Improve Students' Critical Thinking Skills
}

\author{
Wenny Sulistya Ningrum¹, Pratiwi Pujiastuti², Heri Maria Zulfiati3 \\ DOI: $10.35445 /$ alishlah.v13i3.682
}

\begin{tabular}{l}
\hline Article Info \\
\hline Keywords: \\
Critical Thinking Skills; \\
Problem Based \\
Learning; \\
Model \\
Social Sciences Basic \\
Concept
\end{tabular}

Kata kunci:

Keterampilan Berpikir Kritis

Model Problem Based Learning

Konsep Dasar IPS

\begin{abstract}
This research aims to enhance critical thinking abilities through the use of problem-based learning in the Social Science Basic Concepts course. The research method used is Classroom Action Research, which is based on the Kemmis and Taggart model. This research was conducted in two cycle, with the researcher serving as a lecturer and observer during each cycle. The subject of the research was elementary school teacher education. The data collected are presented in table format and analyzed quantitatively in a descriptive manner. The findings indicated that implementing the Problem Based Learning model can help students improve their critical thinking abilities. The results of critical thinking observations in cycle 1 were $39 \%$ (poor), and the results of critical thinking skills tests improved from $26 \%$ (poor) to $54 \%$ (fair). Cycle II was conducted using the same model, and the observation results for critical thinking skills increased from 39\% (poor) to $78 \%$ (good). The increasing of students pass critical thinking skills tests from $54 \%$ (fair) to $91 \%$ (good). It can be concluded that using the Problem Based Learning model can help elementary school teacher education students improve their critical thinking skills.
\end{abstract}

\begin{abstract}
Abstrak
Tujuan penelitian ini adalah untuk meningkatkan keterampilan berpikir kritis mahasiswa dengan menerapkan model Problem Based Learning. Jenis penelitian ini adalah Penelitian Tindakan Kelas, menggunakan model Kemmis \& Taggart. Penelitian ini berlangsung selama dua siklus yakni siklus I dan siklus II, dengan peneliti sebagai dosen dan observer. Subjek penelitian ini adalah mahasiswa Pendidikan Guru Sekolah Dasar. Data yang diperoleh disajikan dalam bentuk tabel, dan dianalisis secara deskriptif kuantitatif. Hasil penelitian menunjukkan bahwa dengan menerapkan model Problem Based Learning dapat meningkatkan proses keterampilan berpikir kritis mahasiswa. Adapun hasil observasi berpikir kritis pada siklus 1 sebesar 39\% (klasifikasi "kurang baik"), hasil peningkatan tes keterampilan berpikir kritis dari 26\% (klasifikasi "kurang baik") menjadi 54\% (klasifikasi "cukup baik"). Siklus II dilakukan dengan model yang sama terjadi peningkatan hasil observasi keterampilan berpikir kritis dari 39\% (klasifikasi "kurang baik") menjadi 78\% (klasifikasi "baik". Hasil peningkatan tes keterampilan berpikir kritis dari 54\% (klasifikasi "cukup baik") menjadi $91 \%$ (klasifikasi "baik"). Disimpulkan bahwa dengan menerapkan model Problem Based Learning dapat meningkatkan keterampilan berpikir kritis mahasiswa Pendidikan Guru Sekolah Dasar.
\end{abstract}

\footnotetext{
${ }^{1}$ Universitas Negeri Yogyakarta, Yogyakarta, Indonesia

Email: wennysulistya.2020@student.uny.ac.id

2 Universitas Negeri Yogyakarta, Yogyakarta, Indonesia

Email: pratiwi@uny.ac.id

3 Universitas Sarjanawiyata Tamansiswa, Yogyakarta, Indonesia

Email: heri.maria@ustjogja.ac.id
} 


\section{INTRODUCTION}

Every student should have the ability to think critically. Problem-solving and decision-making skills can be taught through hands-on experiences in the classroom. Many skills can be developed through critical thinking, such as curiosity and the ability to reduce and consider all possible outcomes. How well a student can ask questions depends on their ability to think critically (Nyet Moi Siew, 2014). Analysis, interpretation, and inference are critical thinking skills, according to Jatmiko et al. (2018). Some of this is based on the assertion made by $\mathrm{Pu}$ et al. (2019) that students' academic performance and abilities are significantly correlated with their critical thinking skills. There are multiple indicators for each of the various categories of necessities. When it comes to the indicators used by researchers Crismasanti and Yunianta (2017), the focus is on questions and arguments and the credibility of a source. As well as memorizing and quickly forgetting theories, critical thinking also entails analyzing and comprehending their meaning and developing social skills. Critical thinking skills should play a greater role in the learning process as a result of this. In addition, Adnan \& Yusri (2016) state that in order to adequately prepare students for the 21st century, educators must focus on developing students' critical thinking abilities. Another claim is that the ability to use critical thinking skills is essential. Because of recent technological advancements, students and teachers now face more challenging problems that require more sophisticated approaches from educators (Ulger, 2018). In light of the current development era's impact on educational competition, students must be equipped with critical thinking skills as a cognitive strategy to solve problems (Ismail et al., 2018) effectively.

Problem Based Learning model can be one of the ways that can improve critical thinking skills. This model has high effectiveness in improving critical thinking skills, with many students applying this model to improve critical thinking skills (Adnan \& Yusri, 2016). In line with this statement, research from Kong et al. (2014) tried to compare the traditional model with the problem-based learning model to improve students' thinking skills. The results obtained that the Problem Based Learning model enhanced skills significantly. Several studies reveal that one of the models that can be used to improve critical thinking skills in students is the Problem Based Learning model. According to Bashith (2017), the Problem Based Learning model is a learning model that uses authentic problems as a context in solving problems and honing critical thinking skills to gain knowledge in learning. It is also explained by Umar et al. (2020) that problem-based learning will produce something positive concerning critical thinking skills and problem-solving. The Problem Based Learning model is considered appropriate to develop students' critical thinking skills in finding and solving problems. This model creates how the problems discussed relate to the real world in everyday life. The characteristics of the Problem Based Learning model are designed to improve inquiry skills, critical thinking, independent learning, social skills, and the ability to investigate everyday problems (Jatmiko et al., 2018). It is undeniable that critical thinking is conceptually related to problem-solving-based learning (Thorndahl \& Stentoft, 2020).

College Students as the $\mathrm{Z}$ Generation need to hone their skills in critical thinking through the Problem Based Learning model (Seibert, 2020). This model invites students to ask questions, analyze, synthesize, interpret, reason, and conclude reasonably. Moreover, in the last few years, students have begun to be tested with challenges that require finding the best solution by paying attention to considerations in making decisions. Observations were made in the Social Science Basic Concepts course. The Basic Concept of Social Studies is a course not far from social life, discussing social studies basics such as sociology, economics, anthropology, politics, and others (Anggraini et al., 2019) and explaining the concepts in social knowledge, especially life and surrounding phenomena (Kristin \& Kencana Sari, 2019). Puspitasari (2020) stated that the basic concept of social studies is a field to hone skills related to master social studies concepts for teaching PGSD teachers in schools. The results of observations on class 2B students at the University of Sarjanawiyata Tamansiswa get a picture of not many students who attend lectures are active. It can be seen from the lack of question and answer process that occurs in class. When lecturers delivered material and the question and answer room was 
opened, only a few students asked questions. The same thing also happened when the lecturer asked a question; only a few students answered the question. The problems found are in line with the results of interviews with lecturers. A lecturer stated that only a few students responded to their questions at the early meeting and even provoked them by mentioning their names to give their opinions and comments. Researchers observe students' critical thinking skills, but it is still not visible. This is the same as the lecturer's statement. The lecturer said that indeed the children were still shy and did not think broadly. Based on the results of observations and early interviews conducted by researchers, it can also be seen that students' skills in expressing ideas and giving opinions tend to be low. This is proven when in the learning process, the teacher invites students to give their ideas and opinions about a case or phenomenon that is presented as material for discussion and analysis. Only a few students were willing to share their opinion unless they were randomly appointed or asked to represent a group. In addition to the above things, the researcher has conducted a pre-action test with $26 \%$ of the targeted $75 \%$. So from this is also what strengthens researchers to improve students' critical thinking skills in the Social Science Basic Concepts course because students will be invited to solve problems and what is suitable to use is the Problem Based Learning model (Rahayu, 2018). Based on these problems, the purpose of this research is to improve students' critical thinking skills by applying the Problem Based Learning model.

Several relevant research, including research from Oktaviyanti \& Novitasari (2019), found that using the Problem Based Learning model can optimally improve students' critical thinking skills in Social Studies Education courses. This is strengthened by the ability of students to think more critically in solving problems using social science and being able to apply them in the environment and everyday life. The same thing was also expressed by Sulistyaningrum et al. (2019) that learning models such as Problem Based Learning and Cooperative Learning can improve students' critical, creative, collaborative, and communicative thinking skills suitable with 21st-century abilities. Subsequent research suggests that HOTS-based learning can improve analytical skills in Social Studies courses. One of the HOTS-based abilities that students must have is the ability to think critically, which produces the ability to analyze a problem in the Social Sciences Learning course (Dewi, 2020). Both previous research and the research in this paper are not much different. This research was carried out entirely by classroom action through digital media, namely, google meet, which is certainly a challenge for researchers and research subjects.

\section{METHODS}

The research design is Classroom Action Research. Classroom action research is research in actions deliberately raised in a class in a learning activity. The classroom action research model used in this research used the Kemmis and McTaggart model. The steps are (1) planning, (2) action I, (3) observation I, (4) reflection I, (5) revised plan I, (6) action II, (7) observation II, (8) reflection II. This research was conducted from March to June of the 2020/2021 academic year. The research was conducted at the Sarjanawiyata University, Yogyakarta. The research subjects were 46 of the 2B PGSD Students academic year 2020/2021. The early hypothesis is how the learning process using the Problem Based Learning model in the Social Science Basic Concepts course can improve the critical thinking skills of 2B students at the University of Sarjanawiyata Tamansiswa. Data collection techniques used are observation and test results of critical thinking skills. Both observations and test questions were used to improve students' critical thinking skills by predetermined indicators in the form of 1) focusing on questions, 2) analyzing arguments, 3) considering the credibility of a source, 4) making deductions and considering induction, 5) make and consider value decisions). The data in this research used quantitative data taken from critical thinking skills tests. The test results are averaged to find individual and classical success according to the set targets. 


\section{FINDINGS AND DISCUSSION}

This research aims to find out how to improve students' critical thinking skills by applying the Problem Based Learning model. The results showed the level of critical thinking skills from observations and tests. There were two Cycles I and II meetings, each with material related to the Basic Concepts of Social Sciences. Four data from observations are then compared between meeting one and meeting two in each cycle. Then the test results were compared between the pre-action scores, Cycle I and Cycle II results.

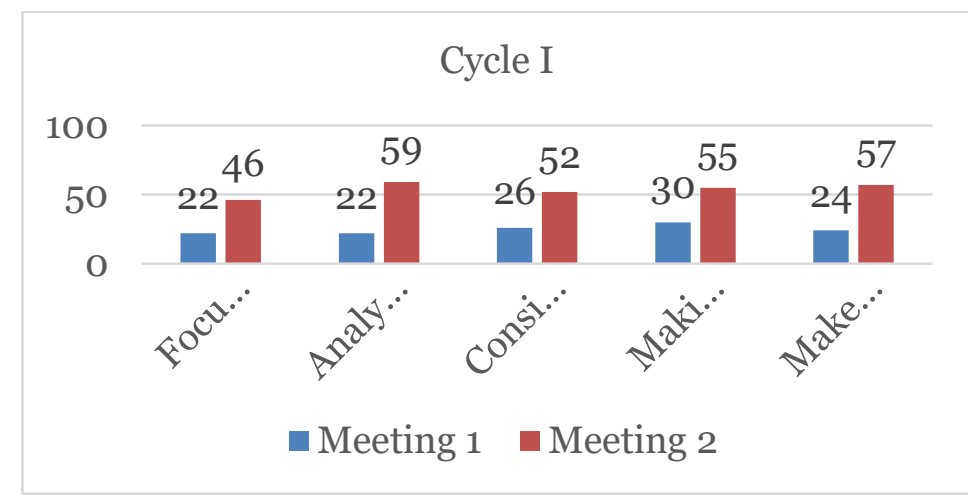

\section{Figure 1. Histogram of Observation Results of Critical Thinking Skills in Cycle I}

Based on the bar chart data obtained from the first cycle of the first meeting and second meeting, the results are at the first meeting the first indicator received $22 \%$, the second indicator was $22 \%$, the third indicator $26 \%$, the fourth indicator $30 \%$, and the fifth indicator $24 \%$. While in the second meeting, the results of the first indicator were $46 \%$, the second indicator was $59 \%$, the third indicator was $52 \%$, the fourth indicator was $55 \%$, and the fifth indicator was $57 \%$. From these results, it was found that there was an increase in students' critical thinking skills through observation. All indicators seem to have increased in almost half of the bar chart. This is undoubtedly a significant change in Cycle I at the second meeting.

Table 1. The Result of the Critical Thinking Skill in Pre-test and Cycle I

\begin{tabular}{llclc}
\hline \hline \multirow{2}{*}{$\begin{array}{l}\text { Score } \\
\text { category }\end{array}$} & \multicolumn{2}{l}{ Pre- } & \multicolumn{2}{c}{ Cycle I } \\
& F & $\%$ & F & $\%$ \\
\hline$<75$ & 34 & $74 \%$ & 21 & $46 \%$ \\
$\geq 75$ & 12 & $26 \%$ & 25 & $54 \%$ \\
\hline \hline
\end{tabular}

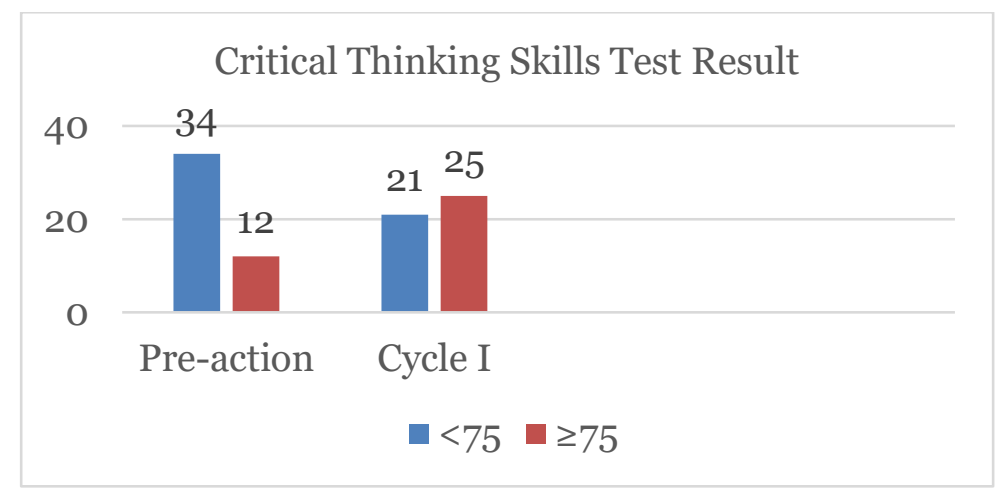

Figure 2. Histogram of Critical Thinking Skills Test Result. 
The data showed that students who scored $<75$ in pre-action were 34 students with a percentage of $74 \%$, and in the first cycle, there were 21 students with a percentage of $46 \%$. Students with a score of 75 in pre-action were 12 students with a percentage of $26 \%$, and in the first cycle, there were 25 students with a percentage $54 \%$. These data indicate an increase in test scores from the histogram. It can be seen clearly that scores $<75$ was decreased number of students, but then scores 75 was increased. It showed the success of action in the first cycle of meetings 1 and 2 significantly.

Classroom action research was conducted at least two cycles to see improvements in each cycle. Therefore, the researchers carried out the stages of Cycle II by continuing to do meetings 1 and 2. These are the results of data collection.

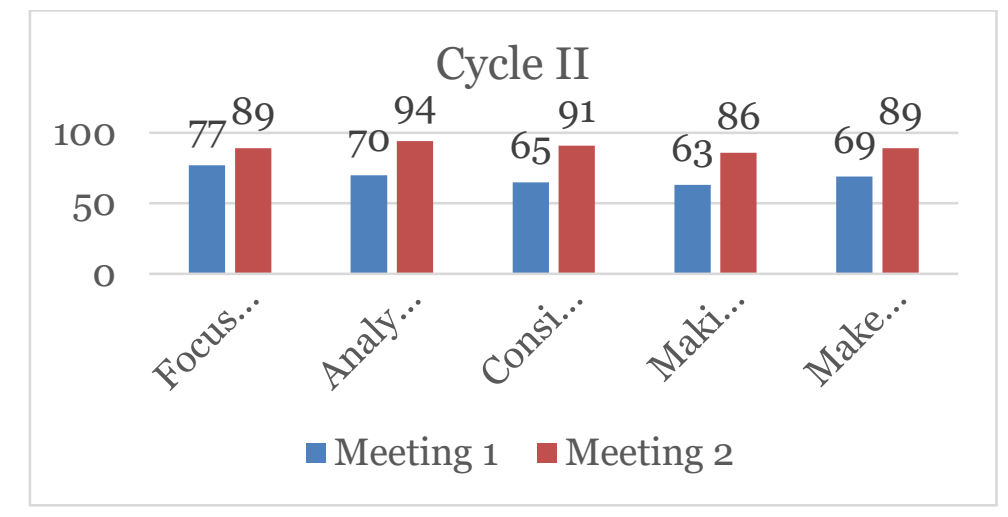

\section{Figure 3. Histogram of Observation Critical Thinking Skill Result in Cycle II.}

Based on the bar chart, the data obtained in Cycle II of the first meeting and second meeting with the results at first meeting the first indicator received $77 \%$, the second indicator $70 \%$, the third indicator $65 \%$, the fourth indicator $63 \%$, and the fifth indicator $69 \%$. While in the second meeting, the results of the first indicator were $89 \%$, the second indicator was $94 \%$, the third indicator was $91 \%$, the fourth indicator was $86 \%$, and the fifth indicator was $89 \%$. These results clearly show that critical thinking skills through observation have improved. Although from Cycle I of the second meeting to cycle II first meeting was not significant enough. However, in Cycle II of the second meeting, there was an increase, which could be observed from the percentage score of each indicator.

Table 2. Critical Thinking Skill Test Result in Cycle I and Cycle II.

\begin{tabular}{lcccc}
\hline \hline $\begin{array}{l}\text { Score } \\
\text { category }\end{array}$ & \multicolumn{2}{l}{ Cycle I } & \multicolumn{2}{c}{ Cycle II } \\
\hline$<75$ & F & $\%$ & F & $\%$ \\
\hline 75 & 21 & $46 \%$ & 4 & $9 \%$ \\
\hline \hline
\end{tabular}




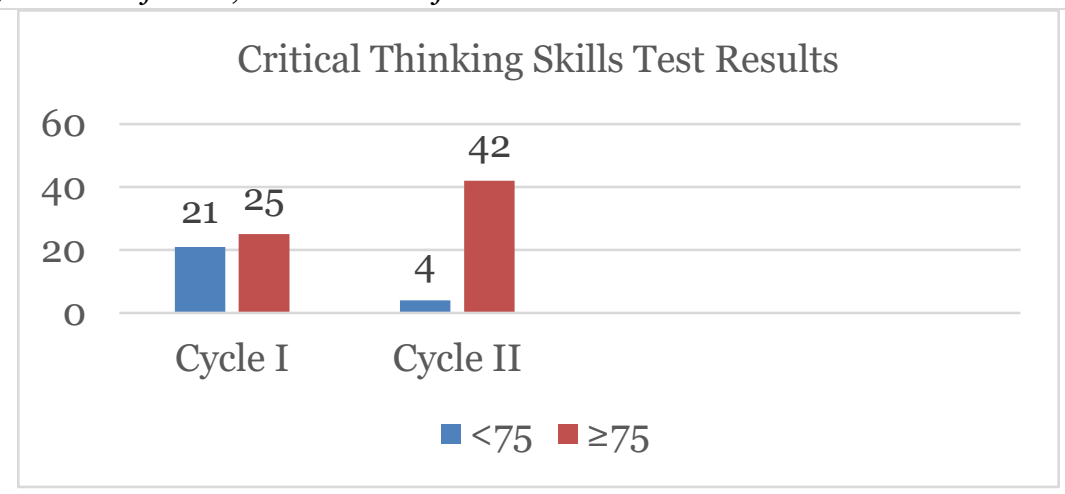

Figure 4. Histogram Critical Thinking Skills Test Results in Cycle II.

It can be seen from the table that students who scored $<75$ in cycle I were 21 students with a percentage of $46 \%$, and in Cycle II as many as 4 students with a percentage of $9 \%$. Students with a score of 75 in cycle I was 25 students with a percentage of $54 \%$, and in cycle II, there were 42 students with a percentage of $91 \%$. These results explain that there has been a success in improving critical thinking skills on the tests given. The significant increase in test scores resulted in the conclusion that The researcher had decided in cycle II as the end of this Classroom Action Research.

The critical thinking skills of 2B students at the Sarjanawiyata Tamansiswa University have improved well. This can be seen from the results of observational analysis and critical thinking skills tests, which show an increase in each indicator in each cycle. Based on the results of the observational analysis of critical thinking skills obtained as follows:

1. The percentage of focus on questions, from Cycle I to first meeting is $22 \%$ it was obtained with a classification of "very poor," the second meeting is $46 \%$ with a category "poor." In Cycle II, there was an improvement. The first meeting obtained $78 \%$ with a classification "good". The second meeting got $89 \%$ with a category "good."

2. The percentage of analyzing the argument in cycle I in the first meeting is $22 \%$ with a classification of "very poor," the second meeting is obtained of $59 \%$ with a classification of "fair." In Cycle II, there is an improvement which is the first meeting obtained $70 \%$ with a classification of "enough," second meeting got $94 \%$ with an excellent category.

3. The percentage considers the credibility of a source, from Cycle I in the first meeting, with the percentage $26 \%$ with the classification "very poor," second meeting is obtained by a percentage of $52 \%$ with the classification "fair," and in Cycle II there is an increase, which is the first meeting, with the percentage $65 \%$ with classification "fair," in the second meeting with the percentage $81 \%$ with a good classification.

4. The percentage of making deductions and considering induction from Cycle I in the first meeting is $30 \%$ with a classification of "very poor," the second meeting with the percentage $55 \%$ with a classification of "fair." In cycle II, there was an increase, which is the first meeting. A percentage of $63 \%$ was obtained with the classification "fair," in the second meeting obtained a percentage of $86 \%$ with a classification "good."

5. The percentage of making and considering the value of decisions from Cycle I in the first meeting is $24 \%$ with a classification "very poor," in second meeting, the percentage is $57 \%$ with a classification of "fair." In Cycle II, there was an increase. In the first meeting, the percentage is $69 \%$ with a classification of "good enough," while in the second meeting, the percentage is $89 \%$ with a classification "good."

The average percentage of observation students' critical thinking skills in Cycle I is 39\%, with a classification of "poor". In Cycle II, the average percentage of students' critical thinking skills increased to $78 \%$ with a classification of "good". The classification has reached the criteria for the success of the action determined by the researcher, so the researcher decided to stop the research. The comparison of 
the average percentage score of critical thinking skills observation in Cycle I and cycle II is presented in the following graph.

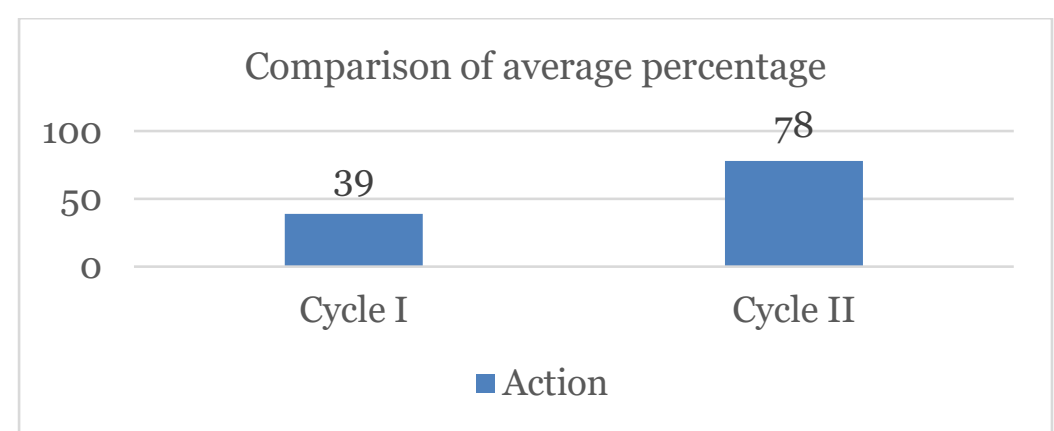

\section{Figure 5. Comparison of Average Percentage of Observation test in Cycle I and Cycle II.}

The test of critical thinking skills of 2B students at the Sarjanawiyata Tamansiswa University in the Social Sciences Basic Concepts course has improved quite well. This can be seen from the percentage of student test results, before the action, there were 12 students or $26 \%$ of students who succeeded in achieving the criteria for the success of the action (75\%) with a classification of "very poor", test results increased in cycle I by $54 \%$ or 25 students who managed to achieve the criteria for the success of the action (75\%) were classified as "good enough", and in Cycle II the test results increased by 91\% or 42 students who succeeded in achieving the criteria for the success of the action (75\%) with the classification "good". This percentage has reached the success criteria for the action (75\%), so the researcher stopped the research in Cycle II. The comparison of the percentage of the number of students who succeeded in achieving the action success criteria set in the Social Science Basic Concepts course through the problem-based learning model before the action, cycle I, and Cycle II are presented in the graph below.

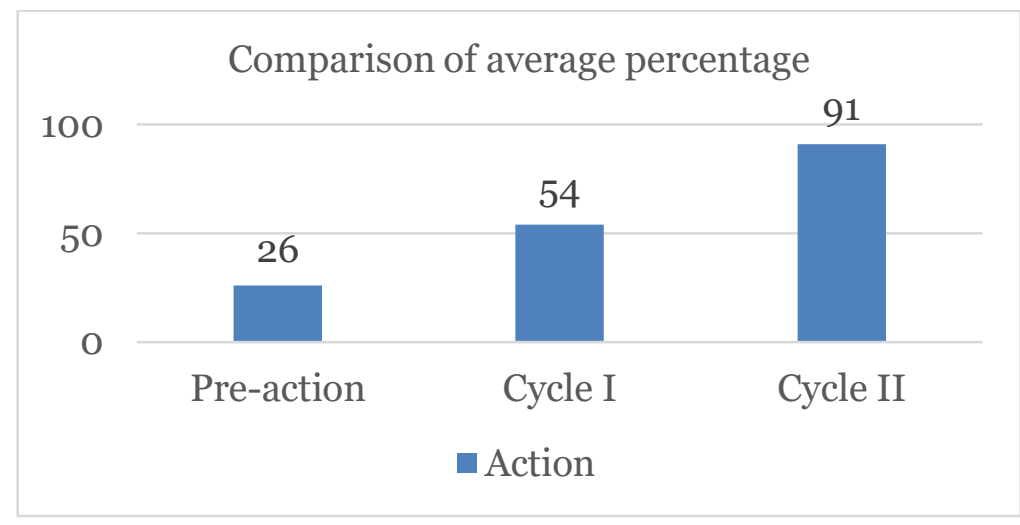

\section{Figure 6. Comparison of Average Percentage of Improvement Result test in Pre-Action, Cycle I, and Cycle II.}

The results of this research are supported by Rahmad et al. (2019) that Problem Based Learning is very effectively used to improve critical thinking skills; besides that, learning activities become more active, and there is even synergy between cognitive, affective, and psychomotor aspects. The application of the Problem Based Learning learning model can improve problem-solving skills. The problems given by the teacher in groups are solved by students accompanied by actively participating in learning to improve problem analysis skills. So that if problem-solving skills increase, it will be accompanied by the increase of students' critical thinking skills. Based on the results that have been achieved during the implementation of learning by applying the Problem Based Learning learning model, students have increased critical thinking skills and occurred in each cycle. Another research stated that the Problem Based Learning model could develop students' critical thinking skills intensively with notes provided 
continuously and accompanied by other models (Anazifa, 2017). The research results from Saputra (2019) stated that by applying the Problem Based Learning model, students in group discussions were able to develop critical thinking and actively take a role in problem-solving. Narmaditya et al. (2018) also get similar results that applying the Problem Based Learning model can improve problem-solving abilities and make conclusions through a critical thinking process.

This research was implemented during the COVID-19 pandemic, where the teaching and learning process was conducted online. However, this does not rule out the possibility that learning and the model applied will fail; in fact, the Problem Based Learning model is suitable to be used during this pandemic situation. This is corroborated by the research results from Nur et al. (2019), which revealed that the Problem Based Learning Model is the best strategy that can be applied in an online class to improve students' critical thinking skills. This research brings fresh air to educators that even though the class is online, the model used can still be innovative and certainly impact. It can be seen in Cycle I, students are less active in participating in learning in the virtual classroom. However, in Cycle II, the students were able to follow, be enthusiastic, and be actively involved, understand the material, and critically respond to other groups' questions. This shows that the problem-based learning syntax is implemented well even though it is in the online classes. During the implementation of classroom action research conducted in two cycles, there was an increase in the quality of learning. This can be seen from the increase in students' critical thinking skills. Improving the quality of learning occurs gradually in each cycle and meeting. The final result aligns with Cahyo's research (2016), which compares conventional models with problem-based learning. The results show that the Problem Based learning model can improve students' critical thinking skills using the gain test.

\section{CONCLUSION}

Students can solve the problems presented in each material in the Social Science Basic Concepts course and improve critical thinking skills through the Problem Based Learning model. Students' critical thinking skills can be activated with the help of the Problem Based Learning model, which can invite students to think critically about existing problems and phenomena and create a vibrant learning atmosphere. Based on the classroom action research that has been carried out, it can be concluded that Problem Based Learning can improve the critical thinking skills of $2 \mathrm{~B}$ students at Sarjanawiyata Tamansiswa University, as evidenced by the success criteria for action, namely $75 \%$ of all students in 2B achieved score 75. In the early situation before the activity, students' critical thinking skills were low, as seen from many students who had not been able to solve Problem-solving and were unable to master the latest phenomena. The students had not actively expressed their opinions. After taking action in cycle I and Cycle II, it is proven that the Problem Based Learning model can hone and improve students' critical thinking skills. Suggestions that can be given, in teaching and learning activities, all elements, both teachers, lecturers, parents, and authorities can use the Problem Based Learning model to improve students' critical thinking skills.

\section{REFERENCES}

Adnan, A., \& Yusri, K. (2016). Prospects of Problem-Based Learning in Building Critical Thinking Skills among Technical College Students in Nigeria. 7(3), 356-365. https://doi.org/10.5901/mjss.2016.v7n3p356

Anazifa, R. D. (2017). Jurnal Pendidikan IPA Indonesia Project-Based Learning And Problem-Based Learning: Are They Effective To Improve Student' $S$ Thinking Skills? 6(2), 346-355. https://doi.org/10.15294/jpii.v6i2.11100

Anggraini, M. S. A., Ismaniati, C., \& Mustadi, A. (2019). Peningkatan Pemahaman Konsep Dasar Ips Mahasiswa Pgsd Melalui Model Cooperative Tipe Gi. DIDAKTIKA TAUHIDI: Jurnal Pendidikan Guru Sekolah Dasar, 6(1), 42. https://doi.org/10.30997/dt.v6i1.1631

Bashith, A. (2017). The Effect of Problem Based Learning on EFL Students 'Critical Thinking Skill and Learning Outcome. 24(2), 93-102.

Cahyo, E. D. (2016). Pengaruh penerapan metode problem based learning dalam meningkatkan pemahaman konsep dasar IPS dan kemampuan berpikir kritis siswa. Jurnal Pedagogik 
Pendidikan Dasar, 4(1),

https://ejournal.upi.edu/index.php/ppd/article/view/21301/10542

Crismasanti, Y. D., \& Yunianta, T. N. H. (2017). Deskripsi Kemampuan Berpikir Kritis Siswa Kelas Vii Smp Dalam Menyelesaikan Masalah Matematika Melalui Tipe Soal Open-Ended Pada Materi Pecahan. Satya Widya, 33(1), 73. https://doi.org/10.24246/j.sw.2017.v33.i1.p73-83

Dewi, P. I. A. (2020). Kuliah Pembelajaran Ips Sekolah Dasar. Widyacarya, 4(1), 94.

Ismail, N. S., Harun, J., Aman, M., Megat, Z., \& Salleh, S. (2018). The Effect of Mobile Problem-Based Learning Application DicScience PBL on Students' Critical Thinking. Thinking Skills and Creativity. https://doi.org/10.1016/j.tsc.2018.04.002

Jatmiko, B., Prahani, B. K., Supardi, Z. A. I., Wicaksono, I., Erlina, N., Pandiangan, P., \& Althaf, R. (2018). ISSN 1648-3898 ISSN 2538-7138 The Comparison Of Or-Ipa Teaching Model And Problem Based Learning Model Effectiveness To Improve Critical Thinking Skills Of Pre-Service Physics Teachers. 300-320.

Kong, L. N., Qin, B., Zhou, Y. qing, Mou, S. yu, \& Gao, H. M. (2014). The effectiveness of problem-based learning on development of nursing students' critical thinking: A systematic review and metaanalysis. International Journal of Nursing Studies. https://doi.org/10.1016/j.ijnurstu.2013.06.009

Kristin, F., \& Kencana Sari, F. (2019). Pengaruh Kedisiplinan Belajar Terhadap Hasil Belajar Mahasiswa dalam Mata Kuliah Konsep Dasar IPS. Jurnal Pendidikan Ilmu Sosial, 28(1), 31. https://doi.org/10.17509/jpis.v28i1.17810

Nur, W., Wan, T., Harun, J., \& Shukor, N. A. (2019). Problem Based Learning to Enhance Students Critical Thinking Skill via Online Tools. 15(1), 14-23. https://doi.org/10.5539/ass.v15n1p14

Nyet Moi Siew, R. M. (2014). THE EFFECTS OF PROBLEM- BASED LEARNING WITH THINKING MAPS ON FIFTH GRADERS 'SCIENCE CRITICAL. 1986, 602-617.

Oktaviyanti, I., \& Novitasari, S. (2019). Analisis Penerapan Problem Based Learning pada Mata Kuliah Pendidikan IPS. Musamus Journal of Primary Education, 2(1), 50-58. https://doi.org/10.35724/musjpe.v2i1.1945

Pu, D., Ni, J., Song, D., Zhang, W., Wang, Y., Wu, L., Wang, X., \& Wang, Y. (2019). Influence of critical thinking disposition on the learning efficiency of problem-based learning in undergraduate medical students. $1-8$.

Puspitasari, N. (2020). Upaya Peningkatkan Hasil Belajar Mahasiswa Pgsd Undaris Melalui Penerapan Pembelajaran Problem Based Learning Pada Mata .... WASPADA (Jurnal Wawasan Pengembangan ..., o1. http://www.ejournal.undaris.ac.id/index.php/waspada/article/view/142

Rahayu, R. (2018). Upaya Peningkatan Hasil Belajar dan Motivasi Belajar Mahasiswa PGSD Universitas Jember Melalui Penerapan Pembelajaran Problem-Based Learning pada Mata Kuliah Konsep Dasar IPS. PEDAGOGIA: Jurnal Pendidikan, $7(1), \quad 53$. https://doi.org/10.21070/pedagogia.v7i1.1616

Rahmad Rifai Lubis, Irwanto, M. Y. H. (2019). Increasing Learning Outcomes and Ability Critical Thinking of Students Through Application Problem Based Learning Strategies. 1(6), 524-527.

Saputra, M. D. (2019). Developing Critical-Thinking Skills through the Collaboration of Jigsaw Model with Problem-Based Learning Model. 12(1), 1077-1094.

Seibert, S. A. (2020). Problem-based learning : A strategy to foster generation Z's critical thinking and perseverance. Teaching and Learning in Nursing, ooo, 2-5. https://doi.org/10.1016/j.teln.2020.09.002

Shandy Narmaditya, B., Wulandari, D., \& Binti Sakarji, S. R. (2018). Does problem-based learning improve critical thinking skills? Cakrawala Pendidikan. https://doi.org/10.21831/cp.v38i3.21548

Sulistyaningrum, H., Winata, A., \& Cacik, S. (2019). Analisis Kemampuan Awal 21st Century Skills Mahasiswa Calon Guru SD. Jurnal Pendidikan Dasar Nusantara, 5(1), 142. https://doi.org/10.29407/jpdn.v5i1.13068

Thorndahl, K. L., \& Stentoft, D. (2020). Thinking critically about critical thinking and prob-lem-based learning in higher education: A scoping review. In Interdisciplinary Journal of Problem-based Learning. https://doi.org/10.14434/ijpbl.v14i1.28773

Ulger, K. (2018). The Effect of Problem-Based Learning on the Creative Thinking and Critical Thinking Disposition of Students in Visual Arts Education The Effect of Problem-Based Learning on the Creative Thinking and Critical. 12(1), 3-6.

Umar, U., Kaharuddin, A., \& Erfan, M. (2020). A Comparative Study on Critical Thinking of Mathematical Problem Solving Using Problem Based Learning and Direct Intruction. 
Al- Ishlah: Jurnal Pendidikan, December 2021, 13 (3), Pages 2585-2594

Wenny Sulistya Ningrum, Pratiwi Pujiastuti, Heri Maria Zulfiati

465(Access 2019), 314-316. 